\title{
A New Method for Calibrating the Kofranyi-Michaelis Respirometer
}

\author{
C. T. M. DAVIES and D. S. SHIRLING \\ From the M.R.C. Environmental Physiology Research Unit, London School of Hygiene and Tropical Medicine, \\ Keppel Street, London, W.C.I \\ and \\ the Department of Physiology, University of Edinburgh
}

A method is described of calibrating the Kofranyi-Michaelis (KM) respirometer under normal laboratory conditions using expired air from a subject exercising in the steady state.

During the calibration procedure the $\mathrm{KM}$ is connected to the subject via a valve and respiratory tubing and placed in a large airtight Perspex box from which an outlet tube passes to a Douglas bag. Calibration is made by comparing during a given time the content and volume of expired air in the Douglas bag with that passing through the meter at several different exercise flow rates.

An example of a typical calibration experiment is given.

The reliability of the Kofranyi-Michaelis (KM) respirometer has now been well established but the instrument has always proved difficult to calibrate accurately under normal laboratory conditions. Several workers have suggested simulation techniques incorporating either Douglas bags (Durnin, 1955) or mechanical interrupter mechanisms (Reindeau and Consolazio, 1959) to produce intermittent flow resembling respiration. However these methods are cumbersome and artificial. From the physiological viewpoint a better method, as suggested by the work of Insull (1954), would be to measure energy cost with the KM and standard bag method simultaneously on subjects exercising in the steady state at various different grades of work increasing in severity. Unfortunately, the present design of the KM precludes this. The major portion of the expired air content is allowed to escape through a diffuse network of holes in the top of the instrument casing. We have overcome this problem by simply placing the $\mathrm{KM}$ in a specially designed Perspex box with a movable lid (Figure) so enabling the accuracy of the meter and sampling device to be tested simultaneously.

A subject is connected via respiratory tubing to the KM respirometer within the box, and the lid is sealed in position by wing nuts. A little petroleum jelly smeared evenly on the rubber inlay inside the lid ensures an air-tight joint. (This can be tested by immersion in water immediately before use.) Expired air passes freely from the $\mathrm{KM}$ to the Douglas bag. A little glycerine spread evenly on the inside of the box opposite the Veeder counter of the $\mathrm{KM}$ prevents condensation and ensures that

Received for publication December 23, 1966.

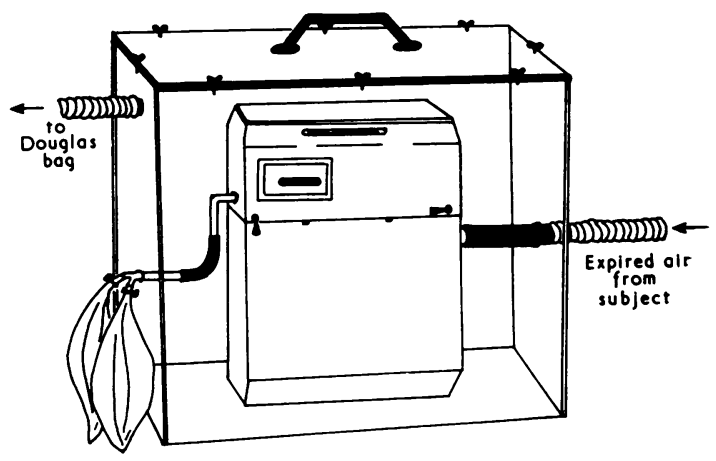

FIGURE. The KM respirometer calibration box.

volume readings can be taken. Five minutes of exercise should be allowed for the subject to reach a 'steady state' and care must be taken during the calibration procedure to ensure that the Veeder counter readings are recorded so as to coincide with the opening and closing of the Douglas bag taps. Representative samples of expired air are collected from the Douglas bag and KM in the usual way. The volume of the Douglas bag can later be ascertained by passage through a wet or dry gas meter. To arrive at the true volume of expired air, the small volume of air in the KM sampling bag must be added to that of the Douglas bag and the usual corrections made for temperature and pressure.

The results of a typical calibration experiment are shown in the Table. From the ventilatory data a calibration chart can be constructed. Thus if the 
TABLE

A Typical Calibration EXPERIMENT

\begin{tabular}{c|c|c|c|c}
\hline \multicolumn{2}{c|}{$\begin{array}{c}\text { Volume of Expired Air } \\
(\text { l./min. S.T.P.D.) }\end{array}$} & $\begin{array}{c}\mathrm{O}_{2} \text { Content of Expired } \\
\text { Air (\%) }\end{array}$ \\
\hline $\begin{array}{c}\text { Douglas } \\
\text { Bag }\end{array}$ & $\begin{array}{c}\text { KM } \\
\text { Respirometer }\end{array}$ & $\begin{array}{c}\text { Correction } \\
\text { Factor }\end{array}$ & $\begin{array}{c}\text { Douglas } \\
\text { Bag }\end{array}$ & $\begin{array}{c}\text { KM } \\
\text { Respirometer }\end{array}$ \\
\hline 9.58 & 9.40 & 1.019 & 14.41 & 14.46 \\
19.50 & 19.19 & 1.016 & 14.83 & 14.80 \\
24.52 & 24.25 & 1.011 & 14.60 & 14.58 \\
33.17 & 32.50 & 1.021 & 14.36 & 14.31 \\
45.54 & 44.36 & 1.027 & 14.89 & 14.88 \\
57.25 & 55.28 & 1.036 & 16.84 & 16.90 \\
\hline
\end{tabular}

meter registers 2251 . of gas passing through the meter in $5 \mathrm{~min}$. then the true pulmonary ventilation will be $\frac{225}{5} \times \mathrm{I} \cdot 027=46.22 \mathrm{l} . / \mathrm{min}$. and this can be corrected to S.T.P.D. or B.T.P.S.

\section{REFERENCES}

Durnin, J. V. G. A. (1955). F. Physiol. (Lond.), 128, 294.

Insull, W. (1954). U.S. Army med. Nutr. Lab. Rep. No. 146.

Riendeau, R. P., and Consolazio, C. F. (1959). f. appl. Physiol., 14, 154.

\section{The April Issue}

The April (1967) issue contains the following papers:-

Industrial Medicine-An Art or a Science T. S. ScotT

Shift and Day Work: A Comparison of Sickness Absence, Lateness, and other Absence Behaviour at an Oil Refinery from 1962 to 1965 P. J. TAYLOR

A Prognostic Study of Occupational Dermatitis Cases in a Chemical Works K. S. WILlIAMSON Hearing Thresholds of a Non-noise-exposed Population in Dundee W. Taylor, J. Pearson, and A. MAIR

Byssinosis among Winders in the Cotton Industry SIZA MEKky, S. A. RoACH, and R. S. F. SCHILLING

A Further Study of China Biscuit Placers in Stoke-on-Trent E. PosNER and M. C. S. KENNEDY Aspects of Pulmonary Mechanics in Arc Welders' Siderosis Dan C. STǎnescu, LaURENTIU Pilat, Niculae Gavrilescu, Dan B. Teculescu, and Iulia Cristescu

Mule Spinners' Cancer and the Wool Industry W. R. LEE and JOAN K. MCCANN

An Evaluation of the Safety of Shrouded Nozzles used on High-pressure Greasing Equipment R. MORLEY

Miscellanea

Ayan Dermatitis J. W. W. MoRgan and JohN Thomson

Pulmonary Hypersensitivity to the Grain Weevil J. A. LuNN and D. T. D. Hughes

Symptoms among Chilli Grinders C. G. URAGODA

Book Reviews

A number of copies are still available and may be obtained from the Publishing Manager, British Medical Association, Tavistock Square, W.C.I, price I8s. $6 d$. 